\title{
Culex nigripalpus Theobald (Diptera, Culicidae) feeding habit at the Parque Ecológico do Tietê, São Paulo, Brazil
}

\author{
Gabriel Z. Laporta ${ }^{1}$, Thaís B. Crivelaro ${ }^{1}$, Elaine C. Vicentin ${ }^{1}$, Priscila Amaro ${ }^{2}$, Maria S. Branquinho \\ \& Maria Anice M. Sallum ${ }^{1}$
}

\begin{abstract}
${ }^{1}$ Departamento de Epidemiologia, Faculdade de Saúde Pública, Universidade de São Paulo. Avenida Dr. Arnaldo, 715, 01246-904 São Paulo-SP, Brasil. gabrielzorelo@usp.br

${ }^{2}$ Superintendência de Controle de Endemias, Secretaria Estadual de Saúde de São Paulo.
\end{abstract}

\begin{abstract}
Culex nigripalpus Theobald (Diptera, Culicidae) feeding habit at the Parque Ecológico do Tietê, São Paulo, Brazil. The blood feeding of a population of $C x$. nigripalpus from Parque Ecológico do Tietê (PET) was investigated using an indirect ELISA protocol. Mosquitoes were captured outside houses. Five hundred sixteen engorged females collected in a reforested area and 25 in an open area were tested. Rodents and dogs were the most common blood sources, accounting for approximately $65.3 \%$ of blood meals. Human blood was detected in $10.9 \%$, dog blood in $26.1 \%$, chicken blood in $2.4 \%$, and rodent blood in $39.2 \%$ of the 541 insects tested. ELISA failed in identifying the blood sources of 233 engorged females, indicating that the mosquitoes may have fed on a host which was not tested. One hundred six individuals were positive for more than one host. The unweighted human blood index was 0.14 and the rodent/human, human/chicken, and dog/rodent feeding index values were $2.70,1.51$, and 1.33 , respectively. Furthermore, rodents are defensive hosts for this haematophagous insect which looks for another host to complete blood-feeding. Considering that rodents are potential reservoirs for Mucambo virus and Saint Louis encephalitis virus and that Cx. nigripalpus feed on the blood of those mammals, we hypothesize that mosquito population in PET could participate in the transmission cycle of those arboviruses. Additionally, this species might be involved in the transmission of Dirofilaria immitis to dogs at this area.
\end{abstract}

KEYWORDS. Disease reservoirs; food chain; insect vectors; parasites; zoonoses.

\begin{abstract}
RESUMO. Hábito alimentar de Culex nigripalpus Theobald (Diptera, Culicidae) no Parque Ecológico do Tietê, São Paulo, Brasil. O hábito alimentar da população de Cx. nigripalpus do Parque Ecológico do Tietê (PET) foi investigado usando um protocolo de ELISA indireto. Foram testadas 516 e 25 fêmeas ingurgitadas e capturadas, respectivamente, em áreas reflorestadas e abertas. Roedores e canídeos foram fontes alimentares mais freqüentes, em aproximadamente 65.3\% dos repastos sangüíneos. De um total de 541 fêmeas ingurgitadas, foram detectadas frequiências de repastos sangüíneos em humanos (10.9\%), canídeos $(26.1 \%)$, galinídeos $(2.4 \%)$ e roedores $(39.2 \%)$. As fontes alimentares de 233 fêmeas ingurgitadas $(43.1 \%)$ não foram identificadas, indicando que essas fêmeas se alimentaram possivelmente de outros hospedeiros não testados. Ainda, houve 106 indivíduos (34.4\%) que fizeram múltiplos repastos sangüíneos. O valor do índice de repastos sangüíneos em humanos foi 0.14 e as razões alimentares foram roedor/humano $=2.70$, humano/galinídeo $=1.51$ e canídeo/roedor $=1.33$. Os roedores são hospedeiros defensivos para esse inseto hematófago o qual não persiste nestes hospedeiros e procura outro para completar o repasto sangüíneo. Considerando que os roedores são reservatórios potenciais de arbovírus Mucambo e São Luís e que Cx. nigripalpus realiza repastos sanguíneos nesses mamíferos, propõe-se a hipótese de que a população deste moquito poderia participar do ciclo de transmissão desses arbovírus no PET. Adicionalmente, esta espécie poderá se envolver na transmissão de Dirofilaria immitis para canídeos neste parque.
\end{abstract}

PALAVRAS-CHAVE. Cadeia alimentar; insetos vetores; parasitas; reservatórios de doenças; zoonoses.

Culex nigripalpus Theobald, 1901 is a competent vector to transmit Saint Louis encephalitis virus in Florida (Nayar et al. 1986; Day \& Stark 2000; Shaman et al. 2003) and Venezuelan equine encephalitis virus in Venezuela (Mendéz et al. 2001). This mosquito occurs in dense, wet, tropical vegetation (Nayar 1968a, b; Day et al. 1990; Day \& Curtis 1993; Guimarães et al. 2000a, b), and can proliferate, opportunistically, in rural areas (O'meara et al. 1989; Forattini et al. 1993, 1994, 1995) where it can be involved in the transmission of pathogens to humans.

The host-feeding habit of this species has been studied by several researchers. Results show that birds are an important blood source for Cx. nigripalpus (Edman \& Webber 1975; Guimarães et al. 1987). Moreover, Edman \& Taylor (1968) observed a seasonal shift in the bird / mammal feeding ratio in Florida. Notwithstanding, Allan et al. (2006) observed higher responses of the $C x$. nigripalpus to volatiles and compounds associated with avian blood when compared to bovine blood in laboratory conditions. In addition, Edman et al. (1974) showed that $C x$. nigripalpus tends to engorge on the most tolerant host of those to which it is exposed. As a result chickens were considered to be tolerant, whereas rodents were defensive hosts. Considering that $C x$. nigripalpus may feed on a variety of hosts, it might have multiple contacts during blood feeding as was observed by Anderson \& Brust (1995).

The Parque Ecológico do Tietê (PET) contains potential reservoirs (mammals and birds), mosquito vectors (Taipe- 
Lagos \& Natal 2003) and the Ilheus virus (Pereira et al. 2001). Consequently, it is plausible to suppose that transmission of arboviruses and filariasis may occur at the PET. Considering that the host-feeding habits of $C x$. nigripalpus have not been investigated at PET and that this species can be a potential vector of pathogens, the objectives of this study are: 1) to investigate the blood-feeding on humans, dogs, chickens, and rodents; 2) to calculate the Human blood index (HBI) and the feeding index; and 3) to discuss the epidemiological importance of the $C x$. nigripalpus population in the PET, São Paulo, Brazil.

\section{MATERIALAND METHODS}

Parque Ecológico do Tietê. The Parque Ecológico do Tietê (PET) (2329' 57" S, 4632'04" W) was created in 1976, with the goal of maintaining the Tietê River floodplain and offering a leisure area for the local community. The PET is administered by São Paulo State government and was established as an Area of Environmental Protection in 1987 (Ecotiete 2007). The area was reforested with native species of the Atlantic forest, and houses such hosts as humans, dogs (Carnivora, Canidae), rodents (Rodentia, Muridae), and chickens (Galliformes, Phasianidae).

Ecological characteristics of sampling areas. There are four ecological zones at the PET: 1) reforested vegetation (native species of Atlantic forest) that provides most of the mammals and birds species and an eutrophized lake; 2) reforested vegetation near the animal reception and care center where birds and mammals are kept in captivity; 3 ) open area that houses the administration and several recreational facilities; and 4) a highly polluted drainage canal. Additionally, a previous mosquito survey carried out in the PET indicated frequency variations of $C x$. nigripalpus among those ecological zones (Taipe-Lagos \& Natal 2003). Therefore, sampling areas named $1,2,3$, and 4 were chosen according to the ecological characteristics mentioned above. Area 1 and Area 2 were both in the reforested area; the former was near the eutrophized lake and the latter near the animal reception and care center. Area 3 was an open area near the administration and Area 4 was at the edge of a drainage canal in the inhabited area.

Mosquito collection and ELISA. Adult sampling was carried out monthly, using a 12-V battery-powered backpack aspirator in areas 1, 2, 3, and 4, in the morning from December 2005 to May 2006. Mosquito samples were transported to the laboratory, where the blood-fed females were identified and individually stored in $2 \mathrm{ml}$ plastic vials containing silica. Bloodfed females in silica were stored at room temperature until they were processed using indirect ELISA. Each female was ground up in a $2 \mathrm{ml}$ vial containing $150 \mu \mathrm{l}$ of phosphate-buffered saline $\mathrm{pH} 7.2$ (PBS). Samples were either tested immediately or frozen at $-20^{\circ} \mathrm{C}$.

The blood inside an engorged female stomach contains host specific Immunoglobulin $\mathrm{G}$ (Ig-G), which is detectable by indirect ELISA technique. The ELISA protocol adopted for the study was standardized according to Beier et al. (1988) and Chow et al. (1993). Subsequently, laboratory experiments were carried out to determine: 1) Reactivity threshold of Ig-G antiserum (capture and conjugated) with homologous and heterologous blood in a block titration method; 2) The best dilution of the capture and the conjugated Ig-G for detecting the host-blood in engorged females; 3 ) If blood-feeding after $6,12,24,36$, and 48 hours would affect the sensibility of the indirect ELISA protocol; and 4) If cross-reactions with homologous and heterologous blood would occur. In addition, we reared Culex quinquefasciatus Say, 1823 in the laboratory to perform experiments 2 and 3 .

All blood-fed adults collected in the field were tested using commercial anti-human, anti-dog, anti-chicken, and anti-rodent Ig-G kits (Kierkegaard \& Perry Laboratories Inc.). Flexible polyvinyl chloride 96-well Costar ${ }^{t m}$ microtitre plates were coated for $1 \mathrm{~h}$ at room temperature with the Ig-G antiserum kit and $50 \mu \mathrm{L}$ of PBS 1x (phosphate-buffered saline) $\mathrm{pH}$ 7.2. Following incubation, we blocked the plates with PBS-T plus Molico Nestle ${ }^{\mathrm{tm}}$ milk $5 \%$ for $1 \mathrm{~h}$ at room temperature and added $50 \mu \mathrm{l}$ of mosquito triturate suspension per well for $2 \mathrm{~h}$ at room temperature. After incubation, the plates were washed three times with PBS-T and incubated for $1 \mathrm{~h}$ at room temperature with $50 \mu \mathrm{l}$ of peroxidase complex (Kierkegaard \& Perry Laboratories Inc.). Following incubation, we washed the plates again three times with PBS-T and added $100 \mu$ of ABTS [2,2‘azino-di(3-ethyl-benzthiazoline sulphonate)-peroxidase substrate solution] (Kierkegaard \& Perry Laboratories Inc.).

The optical density (OD) was read at $405 \mathrm{~nm}$ wavelength in a 230S Organon Teknika ${ }^{\text {tm }}$ plate reader. The negative control (eight $C x$. nigripalpus males) was processed for each plate and the mean OD value of the negative control from each plate was summarized and divided by the number of plates tested. Then, this value was taken as the cut-off point for each OD distribution (e.g. human OD distribution). The positive control was used to adjust the OD variable for each plate. Then, we transformed the crude OD value into a fraction in which the OD value of the positive control was the denominator and the OD of each blood-fed female was the numerator. Finally, all adjusted OD values from each host were joined and distributed on a graph to identify the positive values.

Human Blood Index (HBI). To estimate the human blood index, we adopted the unweighted HBI that represents the frequency of human blood-fed females divided by the frequency of engorged blood-fed females on all hosts.

Feeding Index. We used the feeding index defined by Kay et al. (1979) as the frequency of mosquitoes that fed on one host with respect to another host, divided by the expected frequency of mosquitoes that fed on these two hosts based on the presence of the hosts in the area during the hematophagic period.

Statistical analyses. The mean $(x)$, standard deviation $(s)$, variance $\left(s^{2}\right)$, and standard error $\left(s_{x}\right)$ was calculated from the adjusted OD distributions. Subsequently, we compared the OD distributions to a normal hypothetical distribution using a Kolmogorov-Smirnov test (Z). The Kolmogorov-Smirnov test was applied on the null hypothesis $\left(\mathrm{H}_{0}: \mathrm{OD}=\right.$ Normal $)$ with significance level of 5\%. 


\section{RESULTS}

The best dilution for the capture and the conjugated Ig-G in detecting human, dog, chicken, and rodent blood was, 1/ 6000 and 1/6000 (human); 1/4000 and 1/4000 (dog); 1/4000 and $1 / 6000$ (chicken); and 1/500 and 1/500 (rodent), respectively. Furthermore, we detected no influence for the sensibility of the indirect ELISA protocol whenever females had blood-fed after $6,12,24,36$, and 48 hours. Finally, no cross-reactions with homologous and heterologous blood occurred in laboratory conditions.

From all samples, we recorded 1,092 engorged $C x$. nigripalpus females of which 496 females had an incomplete blood-meal, 541 females were in Sella 2 stage, and 55 females were in stages Sella 3 to 6 . Considering we had standardized this indirect ELISA protocol with laboratory females in Sella 2 stage, the highest sensibility found was for females in Sella 2 stage. Furthermore, we discarded all results from females that had incomplete blood-meals or were in stages Sella 3 to 6. As a result, frequencies of human, dog, chicken, and rodent blood were estimated from the remaining 541 engorged females in Sella 2 stage. Furthermore, of these 541 engorged females, 23 females were collected in Area 1, 493 in Area 2, 12 in Area 3, and 13 in Area 4 and 463 females were collected from December to February (summer) while the remaining 78 were collected between March and May (autumn).

The Kolmogorov-Smirnov test rejected the null hypotheses $(\mathrm{Z}=4.825, \mathrm{p}=0.000)$ for the human OD distribution (Fig. 1), which had $x=0.049, s=0.080, s^{2}=0.006$, and $s_{x}=0.003$. Although the histogram and the normal curve in Figure 1 seem to almost overlap, we observed that the values from 0.372 to 0.960 are out of a normal distribution. The mean cut-off was 0.098 represented in Figure 1 as a reference line. Therefore, all values higher than 0.098 were positive values for human blood. As a result, 59 (10.9\%) females had human blood.

The histogram in Figure 2 is not a normal distribution because it has a bimodal distribution with the first peak between -0.025 and 0.063 and the second peak between 0.675 and 0.938 ; accordingly, the $\mathrm{Z}$ test was $7.210(\mathrm{p}=0.000)$ for the $\operatorname{dog} \mathrm{OD}$ distribution $\left(x=0.190, s=0.311, s^{2}=0.097\right.$, and $\left.s_{x}=0.013\right)$. The mean cut-off was 0.081 and all values higher than it were positive values for dog blood. Consequently, 141 (26.1\%) females had dog blood.

The histogram of the chicken distribution in Figure 3 is

Table I. Distribution of feeding index, presence of the hosts and frequency of blood-feeding according to host, Parque Ecológico do Tietê, São Paulo, from December 2005 to May 2006.

\begin{tabular}{lccccc}
\hline \multicolumn{1}{c}{ Hosts } & Human & Dog & Chicken & Rodent & $\begin{array}{c}\text { Presence of } \\
\text { the host }\end{array}$ \\
\hline Human & 1.00 & 0.28 & 1.51 & 0.37 & 0.75 \\
Dog & 3.59 & 1.00 & 5.44 & 1.33 & 0.50 \\
Chicken & 0.66 & 0.18 & 1.00 & 0.24 & 0.25 \\
$\begin{array}{l}\text { Rodent } \\
\text { Frequency }\end{array}$ & 2.70 & 0.75 & 4.08 & 1.00 & 1.00 \\
$\begin{array}{l}\text { of blood- } \\
\text { feeding }\end{array}$ & $10.9 \%$ & $26.1 \%$ & $2.4 \%$ & $39.2 \%$ & \\
\hline
\end{tabular}

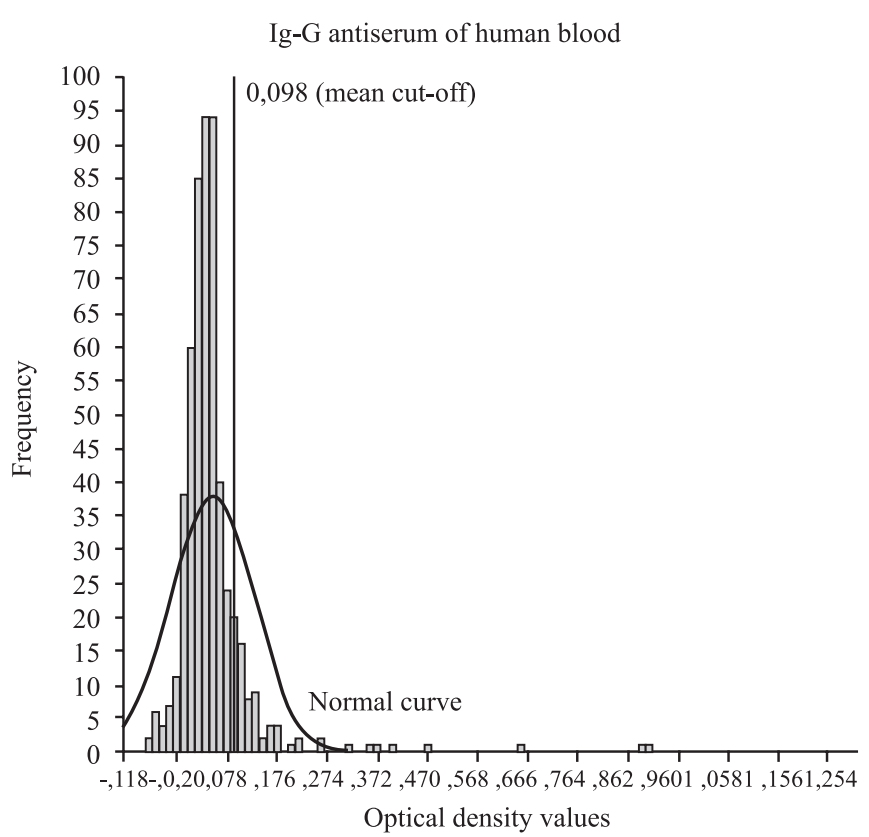

Fig. 1. Distribution of optical density (OD) values of engorged $C x$. nigripalpus females tested by anti-human Ig-G, Parque Ecológico do Tietê, São Paulo, from December 2005 to May 2006.

similar to the histogram of the human distribution because both distributions seem to be related to a normal curve but there were values not expected for a normal distribution (outliers). The $\mathrm{Z}$ test was $7.210(\mathrm{p}=0.000)$ for the chicken OD distribution $\left(x=0.010, s=0.030, s^{2}=0.001\right.$, and $\left.s_{x}=0.001\right)$. All values higher than the mean cut-off of 0.059 were positive for chicken blood. As a result, 13 (2.4\%) females had chicken blood.

Rodent distribution was the nearest to a normal distribution (Fig. 4); however, the values between -0.234 to -0.142 are out of a normal distribution and $\mathrm{Z}=3.179(\mathrm{p}=0.000)$ for this OD distribution $\left(x=0.042, s=0.074, s^{2}=0.006\right.$, and $\left.s_{x}=0.003\right)$. The mean cut-off of 0.060 indicated that all values higher than it were positive for rodent blood. Therefore, 212 (39.2\%) females had rodent blood.

The unweighted HBI was 0.14 for the $C x$. nigripalpus population at the PET. The presence of hosts at the PET (Table I) was used to estimate the expected comparative frequency of mosquitoes feeding on human (0.75), dog (0.50), chicken (0.25), and rodent (1.00). Thus, rodent blood was expected to be in a blood-fed mosquito more than human, dog, and chicken blood. The frequencies of human, dog, chicken, and rodent blood were $10.9 \%, 26.1 \%, 2.4 \%$, and $39.2 \%$, respectively. The feeding index values were calculated using the frequency of blood-fed mosquitoes on human/dog, human/chicken, and human/rodent, divided by $0.75 / 0.50,0.75 / 0.25$, and $0.75 / 1.00$, respectively (Table I).

Additionally, we did not succeed in identifying the blood source of 233 individuals tested $(43.1 \%)$. Besides, from the 541 engorged females tested, 95 samples $(30.8 \%)$ were positive for two blood sources. Six samples had human and dog blood, one sample had human and chicken blood, 21 samples had 


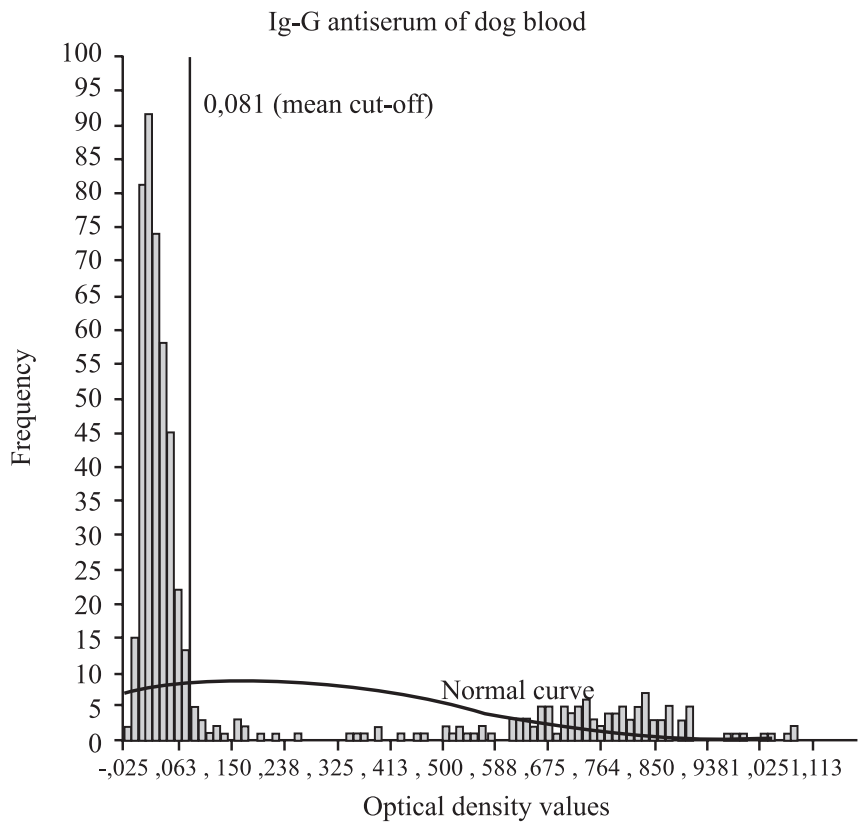

Fig. 2. Distribution of optical density (OD) values of engorged $C x$. nigripalpus females tested by anti-dog Ig-G, Parque Ecológico do Tietê, São Paulo, from December 2005 to May 2006.

human and rodent blood, two samples had dog and chicken blood, 62 samples had dog and rodent blood, and 3 samples had chicken and rodent blood. Also, $3.6 \%$ of the specimens (11 samples) identified by ELISA were positive for three blood sources. Eight samples were positive for human, dog and rodent blood; two samples had dog, chicken, and rodent blood, and one sample had human, chicken, and rodent blood.

\section{DISCUSSION}

The results of the study suggest that $C x$. nigripalpus fed at least on humans, dogs, rodents and chickens. It is also plausible to suppose that this species feeds on other animals, which is indicative that Ig-G antiserum for birds and other mammals should have been used for a better identification of blood feeding habits of $C x$. nigripalpus. According to Alencar et al. (2005), Cx. nigripalpus was demonstrated to have an eclectic feeding habit at the Pantanal, because this species fed on birds, rodents, horses, lizards, cows, water hogs, frogs, and humans; notwithstanding, the highest frequencies were bird blood (38.6\%) and rodent blood $(28.1 \%)$. Furthermore, Edman et al. (1972) observed that in localities in which $C x$. nigripalpus have high density populations, the birds can become increasingly defensive, inducing this mosquito to a diversification of feeding on mammalian hosts including man. Christensen et al. (1996) detected mammal, bird, reptilian, and amphibian blood in Cx. nigripalpus females collected in central Panama, and Gomes et al. (2003) showed the opportunistic behavior of $C x$. nigripalpus in the Paraíba Valley where this species had a non-selective feeding pattern . Therefore, $C x$. nigripalpus is an eclectic blood feeder having a wide range of hosts; besides, it would be interesting to perform an infectivity study, for Ilheus or other arboviruses which are circulating in the city of São Paulo, in this mosquito population at the PET, because this species might be involved in a silent transmission cycle.

There were high frequencies of engorged females with dog blood in Area 2 and during the summer, 132 (94\%) and 112 (79\%), respectively. Considering that dogs were involved in the transmission of Dirofilaria immitis Leidy at Itacoatiara (Labarthe et al. 1998) and Cx. nigripalpus is a natural potential vector of this pathogen in Florida (Sauerman \& Nayar 1983), we speculate that if an infected dog was introduced in Area 2 during the summer, it would be a reservoir for the transmission cycle of this canine heartworm.

The 201 (95\%) blood-fed females with rodent blood in both Area 2 and during the summer indicate that $C x$. nigripalpus might be epidemiologically important, because it is plausible to expect an introduction of a rodent-associated arbovirus in that area and season. Lopes \& Sacchetta (1974) isolated Eastern equine encephalitis (EEE) virus from sentinel mice at the São Paulo Atlantic coast in 1970-71 and Lopes \& Sacchetta (1978) isolated Mucambo virus from specimens of Rattus norvegicus Berkenhout, 1769, at the Serra do Mar. Furthermore those authors detected silent forest cycles of both arboviruses with the involvement of birds and mammals, except horses, and stated the importance of the former to introduce viruses to other forested areas. In addition, there are bird species in the PET such as Tachyphonus coronatus Vieillot, 1822, Turdus rufiventris Vieillot, 1818, Turdus leucomelas Veillot, 1818, and Thraupis sayaca Linnaeus, 1766, from which Mucambo virus was isolated by Lopes \& Sacchetta (1978) at the Serra do Mar in 1968-69. Mucambo virus is a member of the Venezuelan equine encephalitis virus complex and Mendéz et al. (2001) inferred that $C x$. nigripalpus is a competent vector for

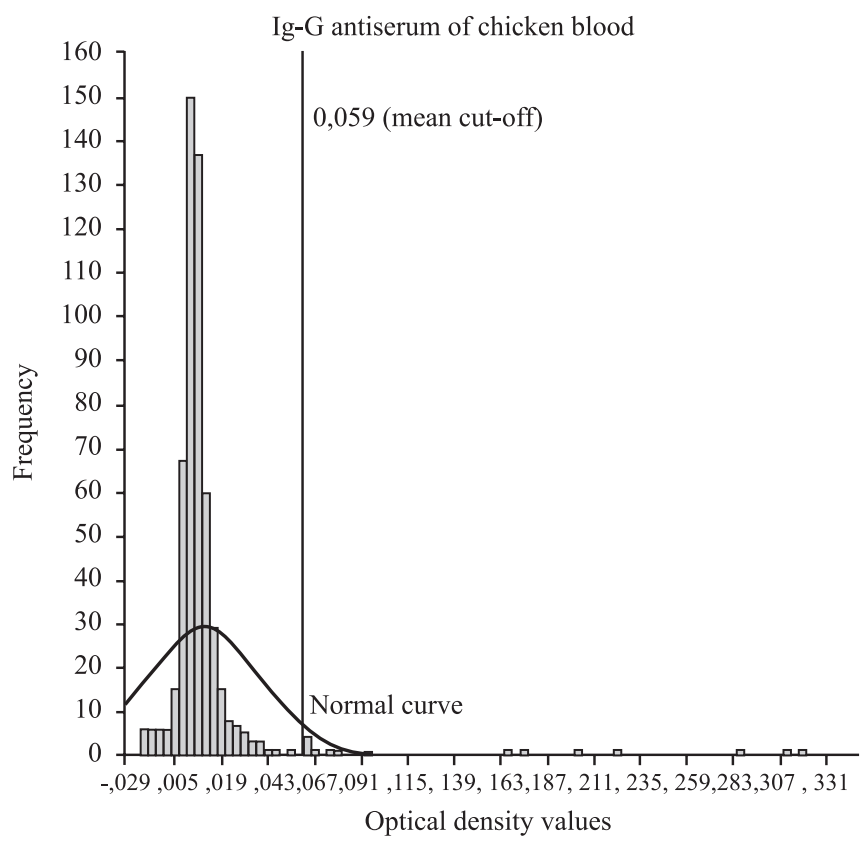

Fig. 3. Distribution of optical density (OD) values of engorged $C x$. nigripalpus females tested by anti-chicken Ig-G, Parque Ecológico do Tietê, São Paulo, from December 2005 to May 2006. 
transmitting arbovirus from this complex. Lopes et al. (1979) isolated Saint Louis encephalitis (SLE) virus from birds, wild rodents, sentinel mice, and Rattus rattus Linnaeus, 1758, in Itapetininga municipality, Serra do Mar, and in São Paulo Atlantic coast in 1967-69. These authors hypothesized that the strain of SLE virus at São Paulo State was not virulent for humans and circulated mainly in the forested areas. However, Rocco et al. (2005) reported the first isolation of SLE virus from a febrile human case suspected to be dengue in São Pedro in 2004 and Santos et al. (2006) indicated that this isolated SLE virus belongs to genotype III, being closely related to an Argentinean strain isolated in 1979 from Culex spp. mosquitoes (Kramer \& Chandler 2001). Furthermore, if an introduction of the SLE virus occurred in the PET, rodents could be reservoirs and $C x$. nigripalpus, which transmits SLE virus in Florida (Nayar et al. 1986; Day \& Stark 2000; Shaman et al. 2003), could be the vector. It is possible to expect an introduction of these arboviruses in Area 2, because it is near the animal reception and care center which receives mammals and birds from forested areas of São Paulo State. Consequently, we recommend an active vigilance procedure such as blood testing of the animals in captivity for detecting arboviruses.

Anderson \& Roitberg (1999) examined potential trade-offs for persistent and non persistent lines of $C x$. nigripalpus that acquire blood from potentially dangerous hosts. Persistent blood feeding paid off when feeding-associated mortality was relatively low to moderate and the non persistent strategy tended to give relatively higher fecundity if the chances of obtaining blood were high. In our research, the high frequencies of incomplete blood-meals (45\%) and multiple host-feeding (34.4\%) occurred mostly because rodents are defensive hosts (Edman et al. 1974) and rodent blood accounted for $39.2 \%$ of the total blood samples. Dogs might be tolerant hosts, because they do not have a nocturnal activity (Alves \& Andriolo 2005) when Cx. nigripalpus are active. An incomplete blood-feeding occurs because the host, such as rodent, becomes defensive for the $C x$. nigripalpus biting activity. Furthermore, we believe that the non persistent lines of Cx. nigripalpus are abundant at the PET, as it was observed by the $45 \%$ of incomplete blood-meals. However, the high frequency of multiple host-feeding (34.4\%) indicates that there is a line of Cx. nigripalpus with a persistent behavior at the PET that would seek another host, maybe a dog or a human, for obtaining a full abdomen of blood. Therefore, this species seems to be an efficient haematophagous insect because it responds with reference to the host's defensive behavior. Furthermore, we hypothesize that the defensive behavior of rodents would affect the vector competence of $C x$. nigripalpus to transmit Mucambo or SLE virus, because rodents may cause $C x$. nigripalpus to engorge incomplete meals with rodent blood and an infected plus persistent $C x$. nigripalpus might transmit one of these arboviruses, first, to a rodent and, subsequently, to another host in the same gonotrophic cycle at the PET.

The HBI values for $C x$. nigripalpus (0.14) indicated low anthropophilic behavior of this species. The feeding index values (rodent $/$ human $=2.70$, human $/$ chicken $=1.51, \mathrm{dog} /$ rodent $=1.33$ ) indicate that dogs and rodents (mammals) are important

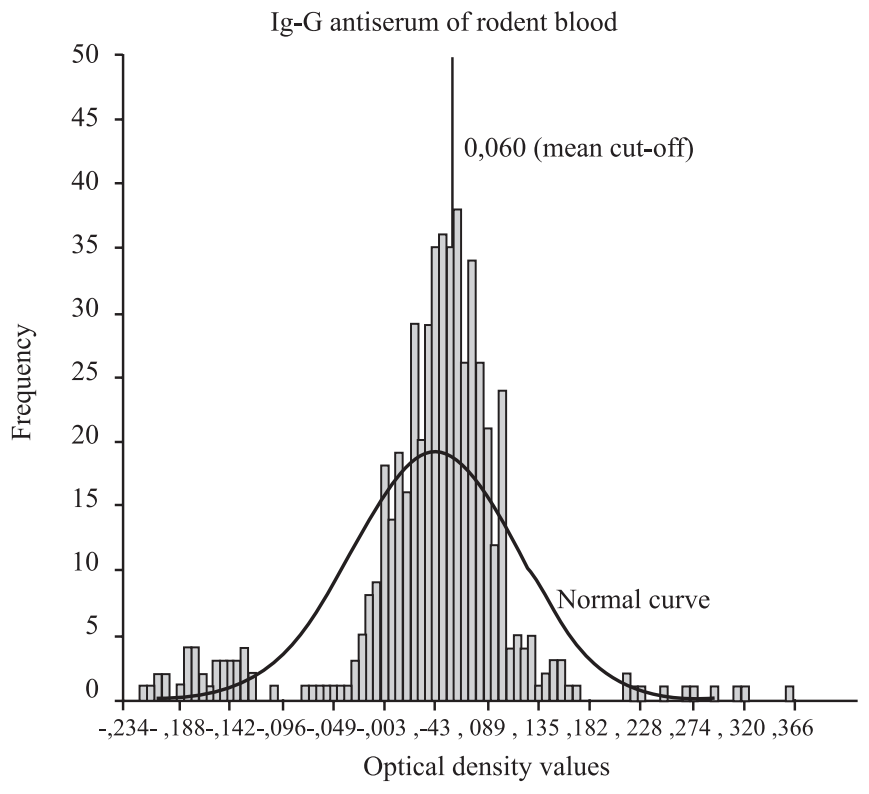

Fig. 4. Distribution of optical density (OD) values of engorged $C x$. nigripalpus females tested by anti-rodent Ig-G, Parque Ecológico do Tietê, São Paulo, from December 2005 to May 2006.

hosts, while humans and chickens are less important hosts at the PET. However, we assume that $C x$. nigripalpus might have an ornitophilic behavior if the negative samples (43.1\%) were tested with anti-bird antiserum. Thus, we infer that this species might be involved in the transmission of Dirofilaria immitis to dogs, and Mucambo and SLE viruses to rodents, which are potential reservoirs, for other animals, including humans, at the PET.

Acknowledgements. This investigation received financial support from Fundação de Amparo à Pesquisa do Estado de São Paulo, Brasil (FAPESP: Grant No. 05/53973-0); Conselho Nacional de Desenvolvimento Científico e Tecnológico, Brasil (CNPq: Grant No. 472485/2006-7); and UNICEF/UNDP/World bank/WHO/TDR, (Grant No. A50252). In addition, GZL received a scholarship from FAPESP (Grant No. 06/53061-3).

\section{REFERENCES}

Alencar, J.; E. S. Lorosa; J. dos S. Silva; C. M. Lopes \& A. E. Guimaraes. 2005. Observations on feeding patterns among mosquitoes (Diptera: Culicidae) in the Pantanal, MT, Brazil. Neotropical Entomology 34: 681-687.

Allan, S. A.; U. R. Bernier \& D. L. Kline. 2006. Attraction of mosquitoes to volatiles associated with blood. Journal of Vector Ecology 31: 71-8.

Alves, L. C. P. S. \& A. Andriolo. 2005. Camera traps used on the mastofaunal survey of Araras Biological Reserve, IEF-RJ. Revista Brasileira de Zoociências 7: 231-246.

Anderson, R. A. \& R. A. Brust. 1995. Field evidence for multiple host contacts during blood feeding by Culex tarsalis, Cx. restuans and Cx. nigripalpus (Diptera: Culicidae). Journal of Medical Entomology 32: 705-710.

Anderson, R. A. \& B. D. Roitberg. 1999. Modelling trade-offs between mortality and fitness associated with persistent blood feeding by mosquitoes. Ecology Letters 2: 98-105. 
Beier, J.; P. V. Perkins; R. A. Wirtz; J. Koros; D. Diggs; T. P. Gargan II \& D. K. Koech. 1988. Bloodmeal identification by direct enzyme linked immunosorbent assay (ELISA), tested on Anopheles (Diptera: Culicidae) in Kenya. Journal of Medical Entomology 25: 9-16.

Chow, E.; R. A. Wirtz \& T. W. Scott. 1993. Identification of blood meals in Aedes aegypti by antibody sandwich enzyme-linked immunosorbent assay. Journal of the American Mosquito Control Association 9: 196-205.

Christensen, H. A.; A. M. de Vasquez \& M. M. Boreham. 1996. Hostfeeding patterns of mosquitoes (Diptera: Culicidae) from Central Panama. American Journal of Tropical Medicine and Hygiene 55: 202-208.

Day, J. F.; G. A. Curtis \& J. D. Edman. 1990. Rainfall-directed oviposition behavior of Culex nigripalpus (Diptera: Culicidae) and its influence on St. Louis encephalitis virus transmission in Indian River County, Florida. Journal of Medical Entomology 27: 43-50.

Day, J. F. \& G. A. Curtis. 1993. Annual emergence patterns of Culex nigripalpus females before, during and after a widespread St. Louis encephalitis epidemic in south Florida. Journal of the American Mosquito Control Association 9: 249-55.

Day, J. F. \& L. M. Stark. 2000. Frequency of Saint Louis encephalitis virus in humans from Florida, USA: 1990-1999. Journal of Medical Entomology 37: 626-633.

Edman, J. D. \& D. J. Taylor. 1968. Culex nigripalpus: seasonal shift in the bird-mammal feeding ratio in a mosquito vector of human encephalitis. Science 161: 67-68.

Edman, J. D.; L. A. Webber \& H. W. Kale. 1972. Effect of mosquito density on the interrelationship of host behavior and mosquito feeding success. American Journal of Tropical Medicine and Hygiene 13: 456-461.

Edman, J. D.; L. A. Webber \& A. A. Schmid. 1974. Effect of host defenses on the feeding pattern of Culex nigripalpus when offered a choice of blood sources. Journal of Parasitology 60: 874883

Edman, J. D. \& L. A. Webber. 1975. Effect of vertebrate size and density on host-selection by caged Culex nigripalpus. Mosquito News 35: 508-512.

Ecotiete. 2007. Histórico e projeto de criação do Parque Ecológico do Tietê. São Paulo. Available on: http://www.ecotiete.sites.uol.com.br. Accessed in: 13 March 2007.

Forattini, O. P.; I. Kakitani; E. Massad \& D. Marucci. 1993. Studies on mosquitoes (Diptera: Culicidae) and anthropic environment. 4Survey of resting adults and synanthropic behaviour in south-eastern Brazil. Revista de Saúde Pública 27: 398-411.

Forattini, O. P.; I. Kakitani; E. Massad \& D. Marucci. 1994. Studies on mosquitoes (Diptera: Culicidae) and anthropic environment. 6Breeding in empty conditions of rice fields in south-eastern Brazil. Revista de Saúde Pública 28: 395-399.

Forattini, O. P.; I. Kakitani; E. Massad \& D. Marucci. 1995. Studies on mosquitoes (Diptera: Culicidae) and anthropic environment. 10Survey of adult behaviour of Culex nigripalpus and other species of Culex (Culex) in south-eastern Brazil. Revista de Saúde Pública 29: 271-278.

Gomes, A. C.; N. N. Silva; G. R. A. M. Marques \& M. Brito. 2003. Hostfeeding patterns of potential human disease vectors in the Paraiba Valley Region, State of Sao Paulo, Brazil. Journal of Vector Ecology 28: 74-78.

Guimarães, A. E.; M. Arlé \& R. N. M. Machado. 1987. Mosquitos no Parque Nacional da Serra dos Órgãos, estado do Rio de Janeiro, Brasil. IV. Preferência Alimentar. Memórias do Instituto Oswaldo Cruz 82: 277-285.

Guimarães, A. E.; C. Gentile; C. M. Lopes \& R. P. Mello. 2000a. Ecology of mosquitoes (Diptera: Culicidae) in areas of Serra do Mar State Park, State of São Paulo, Brazil. II - habitat distribution. Memórias do Instituto Oswaldo Cruz 95: 17-28.

Guimarães, A. E.; C. Gentile; C. M. Lopes \& R. P. de Mello. 2000b. Ecology of mosquitoes (Diptera: Culicidae) in areas of Serra do Mar State Park, State of São Paulo, Brazil. III. Daily biting rhythms and lunar cycle influence. Memórias do Instituto Oswaldo Cruz 95: $753-760$.

Kay, B. H.; P. F. L. Boreham \& J. D. Edman. 1979. Application of the feeding index concept to studies of mosquito host-feeding patterns. Mosquito News 39: 68-72.

Kramer, D. L. \& L. J. Chandler. 2001. Phylogenetic analysis of the envelope gene of St. Louis encephalitis virus. Archives of Virology 146: $2341-2355$.

Labarthe, N.; M. L. Serrão; Y. F. Melo; S. J. de Oliveira \& R. Lourençode-Oliveira. 1998. Mosquito frequency and feeding habits in an enzootic canine dirofilariasis area in Niterói, state of Rio de Janeiro, Brazil. Memórias do Instituto Oswaldo Cruz 93: 145-154.

Lopes, O. S \& L. A. Sacchetta. 1974. Epidemiological studies on eastern equine encephalitis virus in São Paulo, Brazil. Revista do Instituto de Medicina Tropical de São Paulo 16: 253-258.

Lopes, O. S \& L. A. Sacchetta. 1978. Isolation of Mucambo virus, a member of the Venezuelan equine encephalitis virus complex in the State of São Paulo, Brasil. Revista do Instituto de Medicina Tropical de São Paulo 20: 82-86.

Lopes, O. S.; L. A. Sacchetta; T. L. M. Coimbra \& L. E. Pereira. 1979. Isolation of St. Louis encephalitis virus in south Brazil. American Journal of Tropical Medicine and Hygiene 28: 583-585.

Mendéz, W.; J. Liria; J. C. Navarro; C. Z. Garcia; J. E. Freier; R. Salas; S. C. Weaver \& R. Barrera. 2001. Spatial dispersion of adult mosquitoes (Diptera: Culicidae) in a sylvatic focus of Venezuelan Equine Encephalites Virus. Journal of Medical Entomology 38: 813-821.

Nayar, J. K. 1968a. Biology of Culex nigripalpus Theobald (Diptera: Culicidae). 1. Effects of rearing conditions on growth and the diurnal rhythm of pupation and emergence. Journal of Medical Entomology 5: 39-46.

Nayar, J. K. 1968b. The biology of Culex nigripalpus Theobald (Diptera: Culicidae). 2. Adult characteristics at emergence and adult survival without nourishment. Journal of Medical Entomology 5: 203-210.

Nayar, J. K.; L. Rosen \& J. W. Knight. 1986. Experimental vertical transmission of Saint Louis encephalitis virus by Florida mosquitoes. American Journal of Tropical Medicine and Hygiene 35 1296-1301.

O’Meara, G. F.; F. E. Vose \& D. B. Carlson. 1989. Environmental factors influencing oviposition by Culex (Culex) (Diptera: Culicidae) in two types of traps. Journal of Medical Entomology 26: $528-534$.

Pereira, L. E.; A. Suzuki; T. L. M. Coimbra; R. P. Souza \& E. L. B. Chamelet. 2001. Arbovírus Ilheus em aves silvestres (Sporophila caerulescens e Molothrus bonariensis). Revista de Saúde Pública 35: $119-123$.

Rocco, I. M.; C. L. S. Santos; I. Bisordi; S. M. C. N. Petrella; L. E. Pereira; R. P. Souza; T. L. M. Coimbra; T. A. F. Bessa; F. M. Oshiro; L. B. Q. Lima; M. P. Cerroni; A. T. Marti; V. M. Barbosa; G. Katz \& A. Suzuki. 2005. St. Louis encephalitis: first virus isolation from a human in São Paulo State, Brazil. Revista do Instituto de Medicina Tropical de São Paulo 47: 281-285.

Santos, C. L.; M. A. M. Sallum; H. M. Franco; F. M. Oshiro; I. M. Rocco. 2006. Genetic characterization of St. Louis encephalitis virus isolated from human in São Paulo, Brazil. Memórias do Instituto Oswaldo Cruz 101: 57-63.

Sauerman, D. M. \& J. K. Nayar. 1983. A survey for natural potential vectors of Dirofilaria immitis in Vero Beach, Florida. Mosquito News 43: 222-225.

Shaman, J.; J. F. Day \& M. Stieglitz. 2003. St. Louis encephalitis virus in wild birds during the 1990 south Florida epidemic: the importance of drought, wetting conditions, and the emergence of Culex nigripalpus (Diptera: Culicidae) to arboviral amplification and transmission. Journal of Medical Entomology 40: 547-554.

Taipe-Lagos, C. B. \& D. Natal. 2003. Abundância de culicídeos em área metropolitana preservada e suas implicações epidemiológicas. Revista de Saúde Pública 37: 275-279.

Received 07/02/2008; accepted 20/08/2008 